\title{
Supplier Performance Analysis as Transformer Instrument of Shrimp Traceability on Business in East Java
}

\author{
Angky Soedrijanto \\ Doctoral Degree, Faculty of Fisheries and Marine Science Brawijaya University \\ E-mail: angky_umsida@yahoo.com
}

Martani Huseini

Faculty of Social and Politics Science University of Indonesia-Jakarta, Indonesian

Tel: 62-816-720-924 E-mail: martani0703@yahoo.com

Margono Setiawan

Faculty of Economic and Bisnis Unibraw-Malang, 65145, Indonesian

Tel: 62-815-5561-8987 E-mail: feb@brawijaya.ac.id

Eddy Suprayitno

Faculty of Fisheries and Marine Science Unibraw-Malang, 65145, Indonesian

Tel: 62-34-155-3512 Fax: 62-34-1557837 E-mail: faperik@brawijaya.ac.id

Received: January 23, 2013 Accepted: February 20, 2013 Published: June 24, 2013

doi:10.5296/bms.v4i1.3904

URL: http://dx.doi.org/10.5296/bms.v4i1.3904

\begin{abstract}
Introduction of supplying the following aspects of food safety related risks is an urgent need in the shrimp business development in Indonesia. this is in accordance with the Marine and Fisheries Decree number 29 of 2003 and Council Directive 96/23/EC and Article 11 of Council Directive 91/493/EEC which was 2.5. point 3, the results of the European
\end{abstract}




\section{Macrothink}

Commission inspection in 2004. This study aims to identify and locate the role of traceability in the transformer supplying the Indonesian shrimp business, knowing the consistency and commitment of suppliers in the implementation of traceability and to develop a form of implementation of traceability from sea to table shrimp Indonesia. Analysis of supplier performance using the snow ball effect - the balanced score card approach to consistency and commitment. The results showed that the supplier has a performance advantage in the business post-harvest shrimp as well as more consistent and commitment than the performance of the purchasing department at the factory. Consistency and commitment to supplier performance gain in activity scores very high snowball effect that is achieved: the consistency of $82 / 90$ or $91.1 \%$ trust and commitment $=86 / 90=95.6 \%$ or trusts. This performance is better than the performance of the purchasing department to achieve consistency factory $76 / 90=85.6 \%$ or trust and commitment $75 / 90=84.4 \%$ or trusts. Based on these facts the achievements gained in the form of good quality shrimp, weight gain, increase in size and price advantages that definitely is an attraction and stimulation in improving supplier performance motivation. Therefore, the implementation of traceability at the level up stream down stream towards the most appropriate traceability is the active role played by the suppliers.

Keywords: Traceability, Shrimp supplier, Handling 


\section{Introduction}

Shrimp as an export commodity must meet various stringent quality requirements demanded by the factory before being processed. Farmers with shrimp suppliers to ensure quality by performing inspections before harvest of sampling. Among intensive aquaculture, the supplier always trying to politely request shall guarantee to farmers that there is no use of drugs and harmful antibiotics during cultivation.

Use of antibiotics in the post-harvest stage among suppliers would not be done, except the use of chlorine to sterilize water. Supplier profits in the post-harvest only from the lawyer's ice. Peng-es's (icing) or better known as the bin which fits well with the composition of the standard post-shrimp: (ice + water) $=1: 1$ for 24 hours to 72 hours was already able to provide shrimp weight gain between $6 \%$ and of $12 \%$.

Prevention against the shrimp factory suspected to contain residues of antibiotics and taste tests proved 'powerful. This entry dapat'mencegah shrimp containing residues of antibiotics banned by the Government. These efforts correspond Marine and Fisheries Decree number 29 of 2003 and Council Directive 96/23/EC, as reported in the book Drug Index Fish circulated by means of Aquaculture Association of Indonesia (ASPAKINDO).

While the use of antibiotics and hazardous materials in the processing unit is also certainly not going to happen. If every division of the production process carry out their duties in accordance with the correct procedures then the profits can be ascertained factory. Briz, Filipe and Garcia (2007) states that knowledge of systems and food security in developing countries are generally still low.

The application is currently partial traceability by the manufacturer (up stream traceability) has changed the pattern of the work of the farmers and suppliers. Shrimp harvesting is done in large quantities by the supplier in intensive farms in East Java has been implemented independent monitoring process comes with photo documentation of technical work. However, the regulatory process has not yet been applied in the traditional and semi-intensive aquaculture. It is given the limitations of farmers and suppliers include:

1) Limited quantity of harvested shrimp

2) Distance, place and location of farms that are harvested are not necessarily accessible by four wheel drive vehicles

3) Harvesting can not be carried out simultaneously in a short time; generally the harvesting process in a traditional or semi-intensive pond takes a long time

4) The limited utility, especially water

Introduction of supplying the food safety risks associated with an urgent need for the development of Indonesia's shrimp business. EC inspection results were published in 2004: "FINAL REPORT OF A MISSION Carried OUT IN INDONESIA 'held since $15 \mathrm{~s} / \mathrm{d} 23$ April 2004 relating to the efforts of the whole business lines Indonesian fisheries (including shrimp) under Article 11 of Council Directive 91 / 493/EEC are on 2.5. point 3 states that: 
A HACCP plan is was in place in each establishment visited: CCPs cover mainly incoming raw material but do not properly cover hazards during the processing of the products (temperature control for example in establishment without air cooling system in the processing area) as required by Commision Decision 94/356/EC. In a shrimp processing plant, antibiotics residues were identified as a significant hazard at receiving stage; but the control carried out by the establishment was mainly based on guarantee letter from the shrimp supplier, stating the absence of antibiotics.

Given the independence of the actual supplier is able to play an important role in the transformation of the data search to implement traceability from sea to table. There are 4 (four) supplier strategies to gain profits in the shrimp business that ensures non-use of antibiotics by the supplier are:

1) Strategy buy sell wet or dry harvest strategy services; is most common in the work of suppliers. Weighing shrimp before accommodated with ice and water ice in the pond called dry purchases.

2) The standard cutting head (PK), to gain a good head piece and benefit the suppliers often sell shrimp to the plant in the form of head less shell on (HLSO). Accuracy and precision in performing cutting head is key to gain.

3) The standard critique; is technically the only way to save the shrimp are harvested in poor condition, due to illness or other physical factors.

4) Grading strategy. It is the quality and size sorting activity for specific needs of the purchasing department at the factory.

\section{Purpose}

1) Identify and locate the role of suppliers as transformstor traceability in the shrimp business in Indonesia.

2) Knowing the commitment and consistency in the application of traceability supplier.

3) Preparing the form of implementation traceability from sea to table shrimp Indonesia.

\section{Methodology}

Analysis of supplier performance using the snow ball effect - the balanced score card. The principle of measurement performance with a balanced score card is the application of the standard procedure of post-harvest handling of shrimp is to be achieved the highest scores with supplier performance. Thus, supplier performance can be measured by assessing the level of consistency and commitment in carrying out the procedure supplier standards.

Factors consistency and commitment are the basic components that absolutely must be done in the implementation of quality management systems. To be compared, then the achievement of performance based on the consistency and commitment, and is described by the sequence of technical work and the post-harvest shrimp is weighted $0 \mathrm{~s} / \mathrm{d} 10$. Based on the achievement of performance, it may be possible that the performance metrics demonstrate 
achievement of the following sequence of accumulated scores. Through these matrices will be clearly known technical effect the preliminary work can be interpreted as 'small snowballs' (illustrated in the form of a small matrix that contains the technical performance of suppliers) that will affect the creation of a large snowball (effect to: $n$ ).

Through a combination of scores (weighting) will then know the amount of the gap between the application of the standard procedure post-harvest shrimp with consistency and commitment as a measure of supplier performance are analyzed. If there is a percentage value gap of less than $10 \%$ or a trust (confidence level) of more than $90 \%$, the performance can be considered good, and vice versa.

\section{Results and Discussion}

Business and ice water as the main ingredient bin (icing) have been able to guarantee profits for suppliers. Based on the facts it seems clear that the suppliers rely on gains from the increase in weight, increase in size through the process of sorting and catch.

Shrimp from suppliers that go into the whole plant has undergone a process catch at least more than 24 hours. The better the catch made by the supplier will result in an increase in weight, size and good quality as required by the manufacturer.

Process plant catch benefit are:

1) The prawns were received by the factory is clean and fresh. Dirt on the shrimp body washed by water ice for shelter.

2) The texture of the shrimp become easier in the cutting head.

3) Shrimp is more durable and the lining of ice water that will either make shrimp awake from risk of damage.

Table 1. Supplier Performance Tiger Shrimp and Vannamei

\begin{tabular}{|c|c|c|c|}
\hline & 24 hours & 48 hours & 72 hours \\
\hline $\begin{array}{l}\text { Tiger Shrimp Harvest: (assuming } \\
\text { for } 1 \text { ton size } 50 \text { ) } \\
\text { Increase in weight } \\
\text { The increase in size (initial weight } \\
20 \mathrm{~g} / \mathrm{pcs)} \\
\text { Price increases (size } 50=40,000 \text {, } \\
\text { assuming a size up -/kg Rp.500, -) } \\
\text { Increase weigh / ton } \\
\text { The difference in price per ton }\end{array}$ & $\begin{array}{l}6 \% \\
21,2 \text { gr } \\
\text { Rp.41.415,- }\end{array}$ & $\begin{array}{l}9 \% \\
21,8 \mathrm{gr} \\
\text { Rp.42.064,-- }\end{array}$ & $\begin{array}{l}12 \% \\
22,4 \mathrm{gr} \\
\text { Rp.42.679,-- }\end{array}$ \\
\hline $\begin{array}{l}\text { Vannamei Shrimp Harvest: } \\
\text { (assuming for } 1 \text { ton size } 50 \text { ) } \\
\text { Increase in weight } \\
\text { The increase in size (initial weight } \\
20 \mathrm{~g} / \mathrm{pcs} \text { ) }\end{array}$ & $\begin{array}{l}7 \% \\
21,4 \mathrm{gr} \\
\text { Rp.41.636,-- }\end{array}$ & $\begin{array}{l}8 \% \\
21,6 \mathrm{gr} \\
\text { Rp.41.852,-- }\end{array}$ & $\begin{array}{l}10 \% \\
22,0 \mathrm{gr} \\
\text { Rp.42.273,-- }\end{array}$ \\
\hline
\end{tabular}




\section{Macrothink}

\begin{tabular}{|l|l|l|l|}
\hline Price increases (size $50=$ & & \\
Rp.40.000/kg assuming a size up & & & \\
Rp 500,-) & $1.070 \mathrm{~kg}$ & $1.080 \mathrm{~kg}$ & $1.100 \mathrm{~kg}$ \\
Increase weigh / ton & Rp.44.550.000,- & Rp.45.200.000,- & Rp.46.500.000,- \\
The difference in price per ton & & & \\
\hline
\end{tabular}

Table 1 shows that the business benefits suppliers is an increase in weight and size due to water ice. If the process of handling and bin can be implemented, the percentage increase in weight of the above will be obtained will further impact on other aspects that lead to financial gains; situation is technically termed a 'win sampling' and vice versa. Win or lose sampling (purchase) in effect can already be seen from the results of sorting shrimp at harvest. Supplier performance advantage is actually driven by the independence of doing business that result in 'the supplier' more consistent and commitment to the work rather than the purchasing department at the factory. Effects bin which is the sole source of profit for the supplier actually it gives also greater profits for the manufacturer.

Reduced weight means there is also drop-size shrimp, as an illustration: if a shrimp tail decreases only weighs 1 gram for shrimp head on (HO) HO size 25 should weight 40 grams per head when cut to less head (HL) with a yield of $65 \%$ then HL should be obtained weight 26 grams.

Reduced 1 gram due to cutting head which inadvertently will result in reduced also 1 gram multiplied by the number of shrimp tails. If there is 1 ton $=1000 \mathrm{~kg}$ of shrimp HO size 25 then there is a tail of the loss of 25,000 is 25,000 grams or weigh 25 pounds. If the price of shrimp HO size 25 is Rp.60.000, - the value of the money lost by weight because cutting head is Rp.1.500.000, - per ton of shrimp.

Value for money lost due to reduction in size is: when the difference in price of shrimp per size per pound for shrimp headless eg is Rp.3.000, - per pound, the value of the money is going to lose 25 pounds is equivalent to 55.07 pounds is equal Rp.165.000 , -. That amount also does not include the value of the money lost due to deterioration of the standard of shrimp head less to standard shrimp peeling because the skin is damaged abdomen.

Supplier has to understand that buyers buy shrimp from Indonesia per kilogram and sell it retail in destination countries per pieces. Supplier is able to read the purchase price of shrimp by the manufacturer to reflect the performance of buyers who buy shrimp from the factory that supplies it. Perform basic calculations by the supplier by buyers - factory (top-down transformation) as seen in the following table. 
Table 2. Calculation Assumptions Crop Tiger Shrimp Size 30

\begin{tabular}{|c|c|c|c|c|c|c|c|c|}
\hline \multicolumn{5}{|c|}{ HARCEST ROUT HO SAMPLING SIZE 30} & & & & \\
\hline \multicolumn{9}{|c|}{$\begin{array}{l}\text { COMPOSITION TIGER SHRIMP HARVESTED } \\
\text { AT: }\end{array}$} \\
\hline SIZE & SEPARASI & GR HO & PK 63\% & $\begin{array}{ll}1 & \text { TON } \\
\mathrm{HO} & \end{array}$ & $\begin{array}{l}\text { JADI } \\
\text { HL }\end{array}$ & $\begin{array}{l}\text { SIZE } \\
\text { HL }\end{array}$ & $\begin{array}{l}\text { KG } \\
\mathrm{HL}\end{array}$ & $\begin{array}{l}\mathrm{KG} \\
\mathrm{HO}\end{array}$ \\
\hline 25 & $1 \%$ & 40 & 25,2 & 10 & 6,3 & \multirow{4}{*}{$16 / 20$} & \multirow{4}{*}{94,5} & \multirow{4}{*}{150} \\
\hline 26 & $1,50 \%$ & 38,46154 & 24,23077 & 15 & 9,45 & & & \\
\hline 27 & $5 \%$ & 37,03704 & 23,33333 & 50 & 31,5 & & & \\
\hline 28 & $7,50 \%$ & 35,71429 & 22,5 & 75 & 47,25 & & & \\
\hline 29 & $15 \%$ & 34,48276 & 21,72414 & 150 & 94,5 & \multirow{7}{*}{$21 / 25$} & \multirow{7}{*}{$\mathbf{5 3 5 , 5}$} & \multirow{7}{*}{850} \\
\hline 30 & $40 \%$ & 33,33333 & 21 & 400 & 252 & & & \\
\hline 31 & $15 \%$ & 32,25806 & 20,32258 & 150 & 94,5 & & & \\
\hline 32 & $7,50 \%$ & 31,25 & 19,6875 & 75 & 47,25 & & & \\
\hline 33 & $5 \%$ & 30,30303 & 19,09091 & 50 & 31,5 & & & \\
\hline 34 & $1,50 \%$ & 29,41176 & 18,52941 & 15 & 9,45 & & & \\
\hline 35 & $1 \%$ & 28,57143 & 18 & 10 & 6,3 & & & \\
\hline & & & & 1000 & 630 & & & \\
\hline
\end{tabular}

Table 3. Calculation Assumptions Crop Vannamei Shrimp Size 30

\begin{tabular}{|c|c|c|c|c|c|c|c|c|}
\hline \multicolumn{6}{|c|}{$\begin{array}{l}\text { HARVEST ROUT HO SAMPLING SIZE } 30 \\
\text { COMPOSITION HARVESTED VANNAMEI SHRIMP AT: }\end{array}$} & \multirow[b]{2}{*}{$\begin{array}{l}\text { SIZE } \\
\mathrm{HL}\end{array}$} & \multirow[b]{2}{*}{$\begin{array}{l}\text { KG } \\
\text { HL }\end{array}$} & \multirow[b]{2}{*}{$\begin{array}{l}\mathrm{KG} \\
\mathrm{HO}\end{array}$} \\
\hline SIZE & SEPARASI & GR HO & PK 68\% & $\begin{array}{ll}1 & \text { TON } \\
\mathrm{HO} & \end{array}$ & JADI HL & & & \\
\hline 25 & $1 \%$ & 40 & 27,2 & 10 & 6,2 & \multirow{5}{*}{$16 / 20$} & \multirow{5}{*}{186} & \multirow{5}{*}{300} \\
\hline 26 & $1,50 \%$ & 38,46154 & 26,15385 & 15 & 9,3 & & & \\
\hline 27 & $5 \%$ & 37,03704 & 25,18519 & 50 & 31 & & & \\
\hline 28 & $7,50 \%$ & 35,71429 & 24,28571 & 75 & 46,5 & & & \\
\hline 29 & $15 \%$ & 34,48276 & 23,44828 & 150 & 93 & & & \\
\hline 30 & $40 \%$ & 33,33333 & 22,66667 & 400 & 248 & \multirow{6}{*}{$21 / 25$} & \multirow{6}{*}{434} & \multirow{6}{*}{700} \\
\hline 31 & $15 \%$ & 32,25806 & 21,93548 & 150 & 93 & & & \\
\hline 32 & $7,50 \%$ & 31,25 & 21,25 & 75 & 46,5 & & & \\
\hline 33 & $5 \%$ & 30,30303 & 20,60606 & 50 & 31 & & & \\
\hline 34 & $1,50 \%$ & 29,41176 & 20 & 15 & 9,3 & & & \\
\hline 35 & $1 \%$ & 28,57143 & 19,42857 & 10 & 6,2 & & & \\
\hline & & & & 1000 & 620 & & & \\
\hline
\end{tabular}

Based on Table 2 and 3 above it can be seen that the size distribution of less head and vannamei shrimp harvest will be different though from the head on the same size.

As an illustration: to meet factory orders size 16/20 head less, then the supplier should ideally be obtained harvest shrimp head on size 28. Assuming the whole shrimp in a pond size weight 'equal' then mathematically be obtained $100 \%$ (all) harvest is less head size 16/20. In 
fact it is so impossible. Growth of shrimp ponds in the plot as well as any way inevitable deviation cultivation size; then size 28 obtained supplier of crop in a small pond has a large distribution shrimp up and down at least 5 of each size. Facts show that suppliers attempt to meet demand for factory size $16 / 20 \mathrm{HL}$ then the harvest is done is shrimp with head size range on 25 and 30.

The next case is often dijumlai purchase price different between the 2 mill or more, where the factory ' $\mathrm{A}$ ' buy size $16 / 20$ is more expensive than factory 'B' while the factory 'B' to buy shrimp size $21 / 25$ is more expensive than factory 'A '. So foresight supplier to obtain additional profit can be done by sorting size of the lot / shrimp of the same party to be sent to different factories.

Use in implementing the traceability; then this is where the role of commitment and consistent supplier to provide data in search of the 'separation of size' shrimp out of the lot / party to several plant correctly.

Potential malpractice adds weight enhancer ingredients are things that are not possible by the supplier because:

a) Shrimp admission control at the factory on aspects of size and quality in general is very tight, as the purchasing and processing of plant parts will not bear the risk of the claim / rejection by buyers during an inspection or export.

b) Icing is the good and the right way of holding the shrimp can be ascertained will provide an increase in weight and size due to imbibition process. The evidence suggests that bin 24 hours can give rise to $6-7 \%$ by weight and 48-hour bin capable of giving rise to $8-9 \%$ by weight and the bin 72 hours to provide an increase in weight up to $10-12 \%$. Tiger shrimp are generally accommodated between $48 \mathrm{~s} / \mathrm{d} 72$ hours before remitted to the factory, while vannamei shrimp generally accommodated $24 \mathrm{~s} / \mathrm{d} 48 \mathrm{hrs}$ before remitted to the factory.

In order for the facts that occurred in the field can be recorded by the manufacturer and then communicated to the buyers as data traceabliity the necessary prudence in preparing the coding on each bin.

Implementation of traceability can be applied if the supplier has the consistency and commitment. The purchasing department at the plant actually has a function similar to the performance of suppliers: but mentally as a result of workers' monthly pay system is a major cause of low consistency and commitment than the performance of suppliers. This is evident in Table 4 dan Table 5 which proves that consistency and commitment to a better supplier than the purchasing factory. 


\section{Ml Macrothink}

Table 4. Snow Ball Effect Analysis of Balanced Score Card Performance Supplier

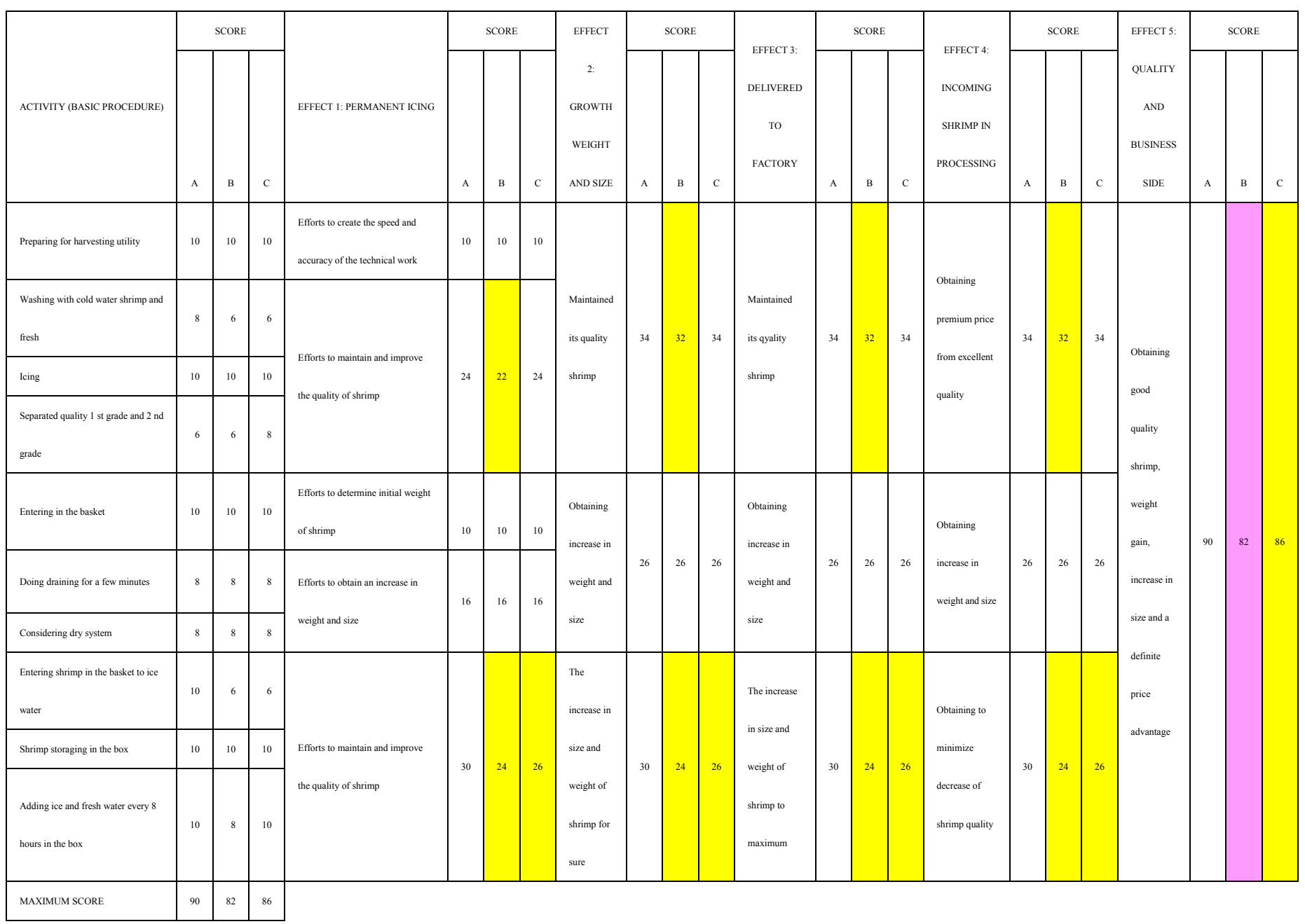

\section{$\%$ TRUST}

$\mathrm{A}=$ Minimum score to be carried out in accordance with procedures

$\mathrm{B}=$ Consistency supplier in carrying out activities (willingness to continuously) = Consistency of $91.1 \%$ (obtained from the calculation of B / A x 100\%)

$\mathrm{C}=$ Commitment supplier activities (seriousness) $=$ Commitment $95.6 \%$ (obtained from the calculation of the C/ A x 100\%) 


\section{MInstitute Macrothink $_{\text {Int }}$}

Table 5. Snow Ball Effect Analysis of Balanced Score Card Performance Factory Purchasing

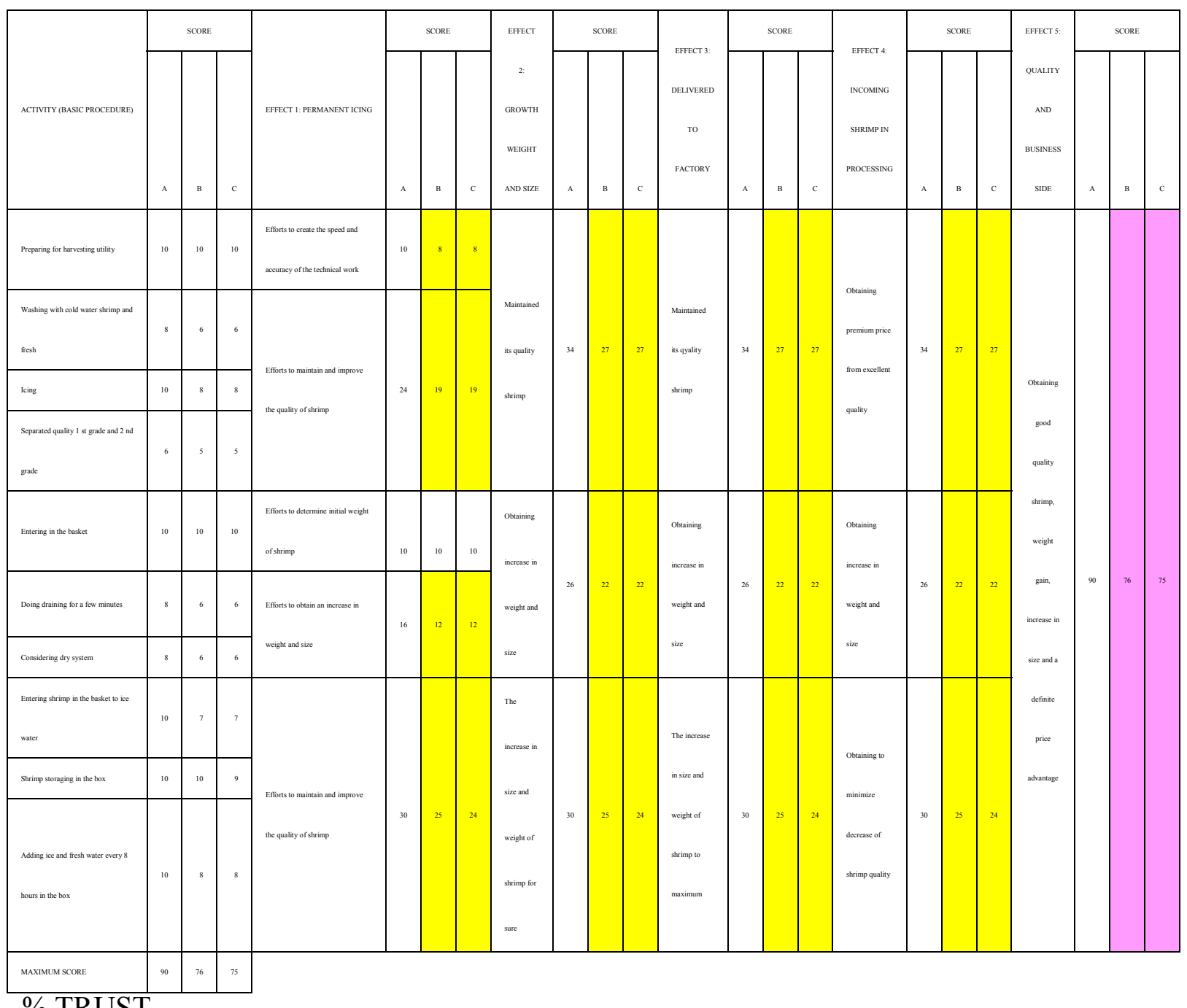

$\%$ TRUST

$\mathrm{A}=$ Minimum score to be carried out in accordance with procedures

$\mathrm{B}=$ The consistency of the purchasing mill in running activity (readiness for continuous) = Consistency of $85.6 \%$ (obtained from the calculation of B / A x 100\%)

$\mathrm{C}=$ Commitment to the purchasing activity plant (seriousness) $=$ Commitment $84.4 \%$ (obtained from the calculation of the C/ A x 100\%)

Consistency and commitment to the performance of suppliers in business activities that take place continuously in the form of scores illustrated a snowball effect is very high, reaching: the consistency of $82 / 90$ or $91.1 \%$ trust and commitment $=86 / 90=95.6 \%$ or trusts. This performance is better than the performance of the purchasing department to achieve consistency factory $76 / 90=85.6 \%$ or trust and commitment $75 / 90=84.4 \%$ or trusts.

This fact has strong reasons are:

1) Seriousness suppliers such as consistency and commitment to do the work of post-harvest standards GHdP based on the fact that: if the post-harvest handling is done poorly or does not match then it is definitely an advantage GHdP not be obtained because: 


\section{Macrothink}

2) Unfavorable perceiver will not cause weight gain, increase in size and quality improvement as expected.

3) Laundering and other improper handling of potentially occur any bandwagon that is not expected in the bin that can lead to contamination of shrimp resulting in lower quality.

4) Sorting or wrong judgment will hurt suppliers themselves due to the loss of a certain volume and mass of each lot / party shrimp.

5) Adherence to the provision of information as a data search to the plant was developed as habituation performance to gain recognition and trust that lead to long-term business cooperation.

\section{Conclusion}

Based on these facts the achievements gained in the form of good quality shrimp, weight gain, increase in size and price advantages that definitely is an attraction and stimulation in improving supplier performance motivation. Therefore, because of the quality, size shrimp, prawns and weight gain is a unity that can be obtained through the implementation of good performance, committed and consistent in the run, then the implementation of traceability at the level up stream down stream towards the most appropriate traceability is played over the role active suppliers.

\section{Acknowledgments}

Prof. Dr. Ir. Kamiso, H.N., M.Sc.; Dr. Ir. Nazori Djazuli, M.Sc.; Dr. Ir. Hardoko, MS.; Ir. Badrus Soleh; Sentit, Haji Kholidin; Ridwan (as dedicated to shrimp supplied to factory in East Java)

\section{References}

Bailey, D. V., Jones, E., \& Dickinson, D. L. (2002). Knowledge management and comparative international strategies on vertical information flow in the global food system. Am J Agric Econ, 84(5), 1337-1344. http://dx.doi.org/10.1111/1467-8276.00399

Clapp S. (2002). A brief history of traceability. Food traceability report. Response for Inst. of Food Technologists Annual Meeting; Anaheim, Calif. Chicago, Ill.: Institute of Food Technologists. Retrieved from http://ift.confex.com/ift/responses/2002/16.doc

Frederiksen M, Osterberg C, Silberg S, Larsen E., \& Bremner A. (2002). Info-Fisk. Development and validation of an internet based traceability system in a Danish domestic fish chain. J Aquat Food Prod Technol, 11(2), 13-34. http://dx.doi.org/10.1300/J030v11n02_03

Hashimoto T, Tanaka K, \& Niwa H. (2003). Trial of farmed fish traceability in Japan. $1^{\text {st }}$ Joint Trans-Atlantic Fisheries Technology Conference-TAFT 2003; 2003 June 11-4; Reykjavik.

Julian Briz, Isabel De Felipe, \& Marian García. (2007). Food Safety in Agricultural International Trade: The Spanish experience in Mediterranean products Universidad 


\section{Macrothink}

Politecnica Madrid, Spain; Imperial College, UK Contributed Paper prepared for presentation at the 105th EAAE seminar 'International Marketing and International Trade of Quality Food Products', Bologna, Italy, March 8-10.

Krissoff, B., Kuchler, F., Nelson, K., Perry, J., \& Somwaru, A. (2004). Country-of-origin labeling: theory and observations. Outlook. Economic Research Service, U.S. Dept. of Agriculture.

Westgren, R. E. (1999). Delivering food safety, food quality, and sustainable production practices: the label rouge poultry system in France. Am J Agric Econ, 81(5), 1107-1111. http://dx.doi.org/10.2307/1244092

WRS-04-02. (2004). ERS: Washington, D. C. Retrieved from http: |Wwww.ers.usda.gov/publications/WRS04/jan04/wrs0402/ 